Journal of Advanced Research in

Fluid Mechanics and Thermal

Sciences

Journal homepage: www.akademiabaru.com/arfmts.html

ISSN: 2289-7879

\title{
Analytical Study of Performance and Emission Characteristics of a Palm Biodiesel Fuelled Engine using Response Surface Methodology
}

\author{
Yew Heng Teoh ${ }^{1,}{ }^{*}$, Balakrishnan Navaneetha Krishnan ${ }^{1}$, Heoy Geok How ${ }^{2}$, Shangeetha Ganesan ${ }^{3}$, \\ Kok Hwa Yu ${ }^{1}$, Hishammudin Afifi Huspi ${ }^{1}$

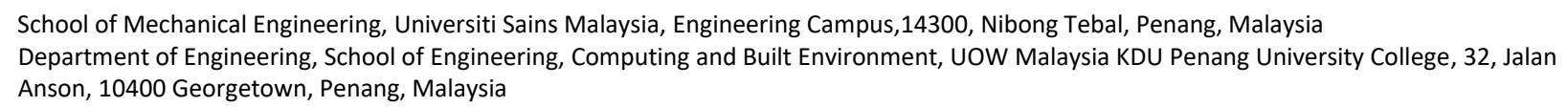

\section{Article history:}

Received 20 March 2020

Received in revised form 11 June 2020

Accepted 13 June 2020

Available online 3 September 2020

Keywords:

Palm oil; Diesel; Response Surface Methodology

\begin{abstract}
Alternative fuels are in the limelight due to depleting fossil fuel reserves and alarming environmental impact of pollution. Even though electric mobility is encouraged by the government to reduce the dependence on fossil fuel, lack of high energy density batteries still downplays the mass marketable scope of electric vehicles due to drivable range in which liquid fueled vehicles have the advantage. Response Surface Methodology (RSM), a statistical mathematic technique is utilized to analytically study the impacts of Palm Biodiesel (PBD) blended diesel fuel at enrichment ratio of $10 \%, 20 \%$, and $40 \%$ on performance and emission characteristics of a multi cylinder compression ignition (Cl) engine. The study concludes that engine torque and power improve with mild palm oil enrichment of $10 \%$ notably at low end speed of $2000 \mathrm{rpm} . \mathrm{CO}_{2}$ and $\mathrm{CO}$ emissions and smoke decline while higher $\mathrm{O}_{2}$ content present in PBD compared to pure Diesel gives rise to $\mathrm{NO}_{\mathrm{x}}$ emissions.
\end{abstract}

\section{Introduction}

Energy has become a great ingredient for humans to achieve and maintain industrial growth but this especially fossil fuels come at a cost of environmental and ecological threat. The threat posed by conventional fuels has forced law makers to deploy stringent laws to curb pollution. Biodiesel is an alternative to fossil fuels and when Malaysia is taken into importance along with other south east Asian countries, the abundance of palm derived biodiesels is a major boon to the community $[1,2]$.

\footnotetext{
* Corresponding author.

E-mail address: yewhengteoh@usm.my

https://doi.org/10.37934/arfmts.75.1.127136
} 
Biodiesels are advantageous considering its factors like bio-degradable, non-toxic, lower sulfur content and lower engine emissions but its disadvantage is lower power delivery in engines [3].

A number of researchers have conducted studies on a variety of biodiesels. Abed et al., [4] have studied the effects of biodiesels derived from Waste Cooking Oil (WCO), Palm, Jatropha and Algae on emission and report lower values of $\mathrm{CO}, \mathrm{HC}$ and smoke when compared to diesel but $\mathrm{NO}_{\mathrm{x}}$ and $\mathrm{CO}_{2}$ increase. Bari and Hossain [5] have conducted experiment to determine engine out responses using palm oil and conclude that the oxygen molecule present in fuel reduces pollutants like $\mathrm{CO}$ and $\mathrm{HC}$ but low calorific value reduces BSFC when compared to diesel fueled operation. Palm oil blend of $20 \%$ in diesel was used to study the combustion characteristics of a Compression Ignition $(\mathrm{Cl})$ engine, Rosha et al., [6] report that ignition delay lowers while peak cylinder pressure and Brake Thermal Efficiency (BTE) raises with increasing Compression Ratio (CR). Researchers have optimized engine operating characteristics using RSM for a variety of fuels, to name a few such as fried oil methyl ester, hydrous ethanol, iso-butanol and methanol [7-10]. Based upon the work carried out by previous researchers, it was understood that there was a knowledge gap particularly in using RSM analysis for engine fuelled by PBD blended fuel for RSM analysis based on experimental engine test results. Thus, this study is undertaken to establish possible findings.

\section{Methodology}

The present investigation was carried out using 4 different fuel samples which includes baseline diesel and Palm biodiesel blends here after notated as PBD10, PBD20 and PBD40. Fuel blends were manually prepared by agitating proportionate volume of diesel and PBD in a sealed container. Mass and volume of each fuel was measured to calculate density using the formula as stated by Karmakar et al., [11]. A pycnometer kept at $25^{\circ} \mathrm{C}$ was used to measure the volume. The composition of the used fuels is presented in Table 1. The engine was tested at Wide Open Throttle (WOT) condition at varying speed range from $1000 \mathrm{rpm}$ to $3500 \mathrm{rpm}$ with an interval of $500 \mathrm{rpm}$.

Table 1

Composition and properties of fuel blend

\begin{tabular}{lllll}
\hline $\begin{array}{l}\text { Fuel } \\
\text { type }\end{array}$ & $\begin{array}{l}\text { Palm Biodiesel } \\
\text { proportion in Diesel }(\%)\end{array}$ & $\begin{array}{l}\text { Fuel Density } \\
(\mathrm{g} / \mathrm{ml})\end{array}$ & $\begin{array}{l}\text { Kinematic Viscosity } \\
\text { at } 40^{\circ} \mathrm{C}\left(\mathrm{mm}^{2} / \mathrm{s}\right)[12]\end{array}$ & $\begin{array}{l}\text { Calorific Value } \\
(\mathrm{kJ} / \mathrm{kg})[12]\end{array}$ \\
\hline Diesel & 0 & 833.7 & 3.0625 & 45,632 \\
PBD10 & 10 & 836.3 & 3.8379 & 45,120 \\
PBD20 & 20 & 838.8 & 3.9180 & 44,609 \\
PBD40 & 40 & 844.7 & 4.1510 & 43,474 \\
\hline
\end{tabular}

A 4-cylinder medium-duty diesel engine which featured mechanical fuel injection system and turbocharger was used in this study. The specifications are shown in Table 2.

Table 2

Engine specifications

\begin{tabular}{|c|c|c|c|c|c|}
\hline $\begin{array}{l}\text { Make and } \\
\text { Model }\end{array}$ & Type & $\begin{array}{l}\text { Fuel Injection } \\
\text { System }\end{array}$ & Combustion Type & Displacement & $\begin{array}{l}\text { Compression } \\
\text { Ratio }\end{array}$ \\
\hline $\begin{array}{l}\text { Ford } 1.8 \text { XLD } \\
418 \mathrm{~T}\end{array}$ & $\begin{array}{l}\text { 4-stroke, four- } \\
\text { cylinder diesel } \\
\text { turbocharged, } \\
\text { water-cooled }\end{array}$ & $\begin{array}{l}\text { Lucas DPC type } \\
\text { fuel-injection } \\
\text { pump, single- } \\
\text { point fuel } \\
\text { injectors }\end{array}$ & $\begin{array}{l}\text { Indirect injection } \\
\text { (IDI) with pre- } \\
\text { combustion } \\
\text { chamber }\end{array}$ & $1.8 \mathrm{~L}$ & 21.50: 1 \\
\hline
\end{tabular}


An eddy current type Scheneck W130 engine dynamometer with the peak absorbing power of $130 \mathrm{~kW}$ was used to control the speed and torque of the engine, as shown in Figure 1. For fuel consumption measurement, a Kobold oval gear type fuel flow meter was employed. Gaseous emissions and smoke opacity in engine-out exhaust was detected by SPTC AUTOCHECK 5-gas analyser and smoke analyser. Collected data was later analysed for Response Surface Methodology (RSM) using Design Expert, a licenced software by Stat Ease, which also used by most of the researchers [13-16].

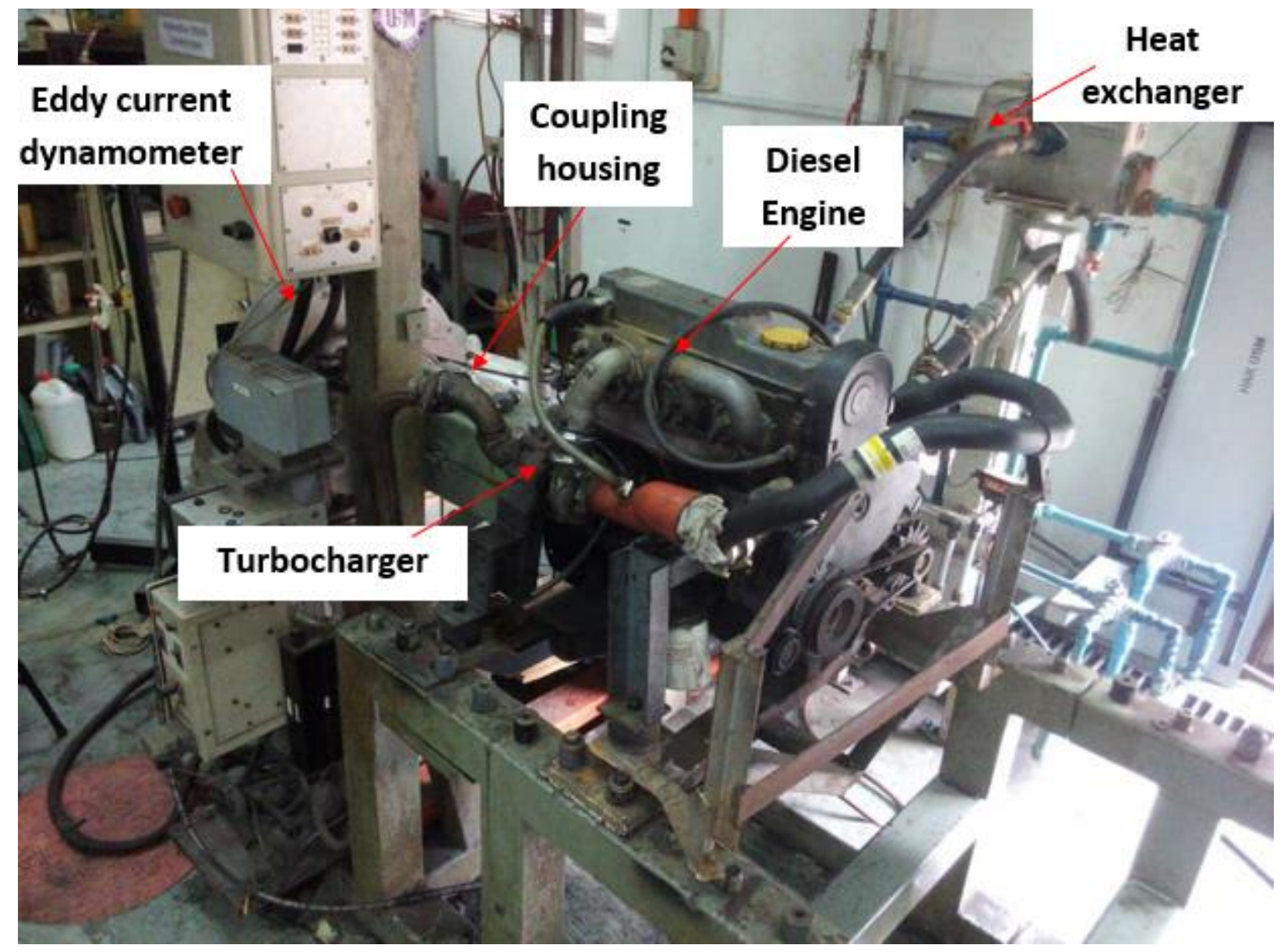

Fig. 1. Engine and dynamometer arrangement setup

\section{Results and Discussions}

\subsection{Performance}

Power can be stated as a function of torque and speed. From Figure 2, it is understood that peak power operating region spreads across the speed range approximately from $1750 \mathrm{rpm}$ to $3250 \mathrm{rpm}$ for baseline fuel diesel and PBD blend of $10-40 \%$. As brought out by several researchers, this can be attributed to higher viscosity, lower calorific value and density of PBD fuel [17-23]. Higher value of fuel density and kinematic viscosity can have an adverse effect on air-fuel mixing due to poor fuel atomisation. This phenomenon in turn results in combustion instability and thus lowers power. Lower cetane number reduces combustion quality as chances of self-ignition of fuel are better with high cetane number giving shorter ignition delay. Higher peak in-cylinder pressure and high Heat Release Rate (HRR) at pre-mixed combustion phase is possible with shorter ignition delay. This kind of desired combustion quality elevates the need for high cetane number fuel. Highest power of $29.6 \mathrm{hp}$ at 2000 rpm is obtained for PBD10 compared to $28.7 \mathrm{hp}$ at $2000 \mathrm{rpm}$ for pure diesel fuelling. 


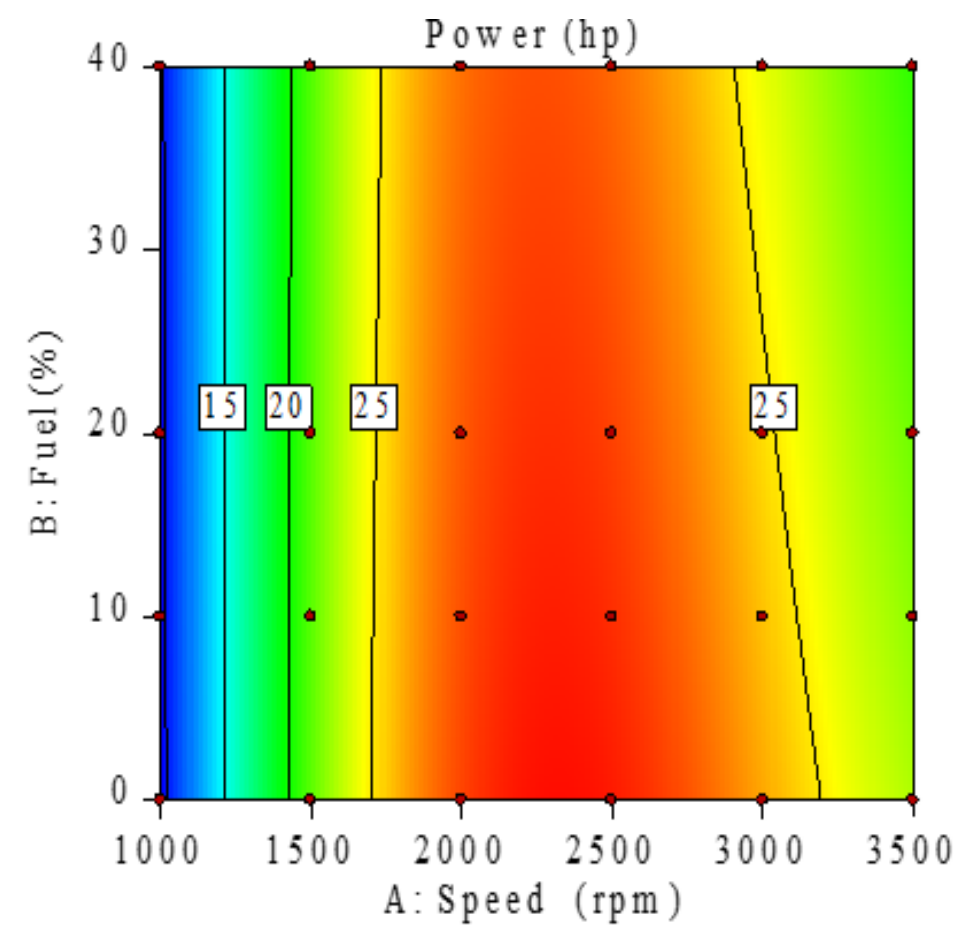

Fig. 2. Interactive effect of fuel blend and speed on engine power

Torque is a measure of rotational effort on crankshaft by piston otherwise an opposing force developed to counteract the torsional resistance (load). As seen from Figure 3, peak torque operating region in speed range approximately from $1000 \mathrm{rpm}$ up to $2000 \mathrm{rpm}$ for baseline fuel diesel and PBD blends satisfactorily up to $80 \%$. Highest torque of $102.2 \mathrm{Nm}$ is attained with pure diesel fuelling at $2000 \mathrm{rpm}$ and $105.5 \mathrm{Nm}$ for PBD10, after which a downward trend is observed for the rest of PBD fuel blends. Factors like low engine speed, higher viscosity and lower heating value and calorific value, longer ignition delay and cetane number of fuels can reduce engine torque $[24,25]$.

Brake Specific Fuel Consumption (BSFC) is a measure of fuel efficiency and can be defined as rate of fuel consumption divided by power developed. As seen from Figure 4, the optimum BSFC operating region in speed range from $1000 \mathrm{rpm}$ to $2500 \mathrm{rpm}$ after which it slims down for baseline diesel fuel and PBD blends all the way up to $40 \%$. Lowest BSFC is attained for diesel at $328.4 \mathrm{~g} / \mathrm{kWh}$ and 326.3 $\mathrm{g} / \mathrm{kWh}$ for PBD10 at $2000 \mathrm{rpm}$. BSFC is influenced by several factors of fuel properties such as calorific value, density and viscosity. Fuel injection pump injects more PBD blended fuel mass than pure diesel mass due to higher density of PBD for the same power. For comparison, diesel has a density of 833.7 $\mathrm{g} / \mathrm{ml}$ whereas PBD20 and PBD40 have density of $838.8 \mathrm{~g} / \mathrm{ml}$ and $844.7 \mathrm{~g} / \mathrm{ml}$, respectively, as shown in Table 1. Poor atomisation of fuel caused by higher kinematic viscosity of PBD increases BSFC. These attributes have well been highlighted by various researchers in their work [20,26-28]. 


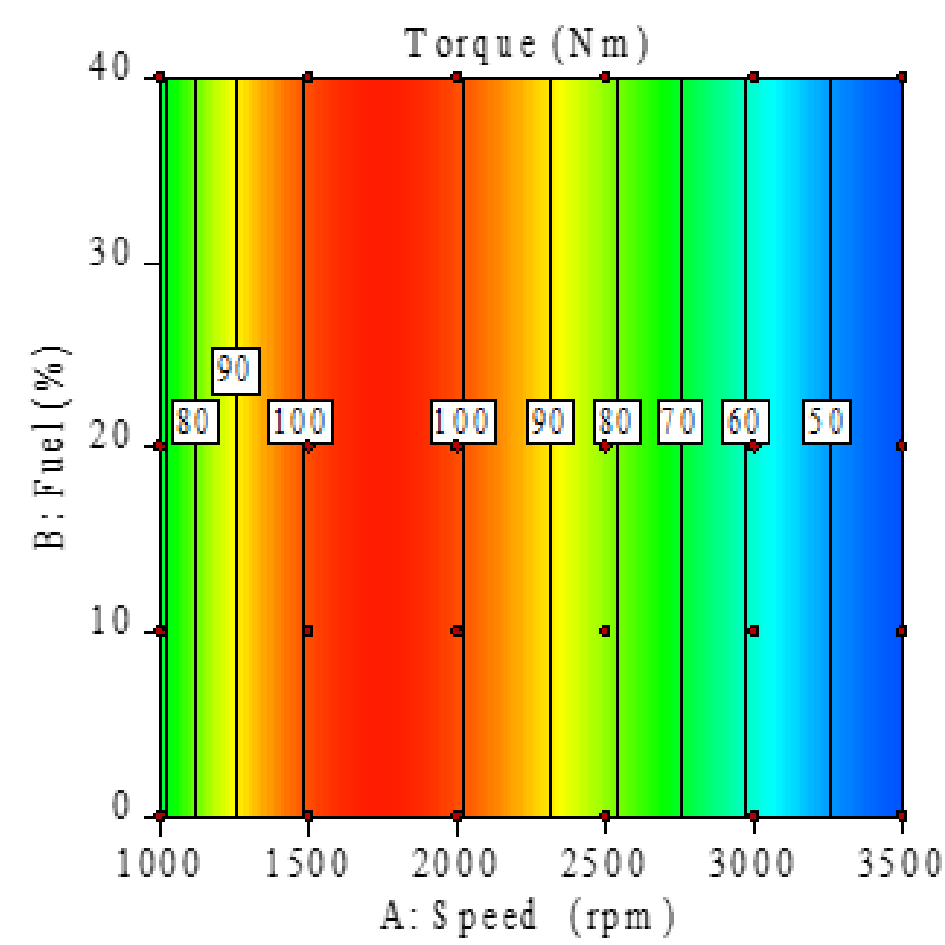

Fig. 3. Interactive effect of fuel blend and speed on torque

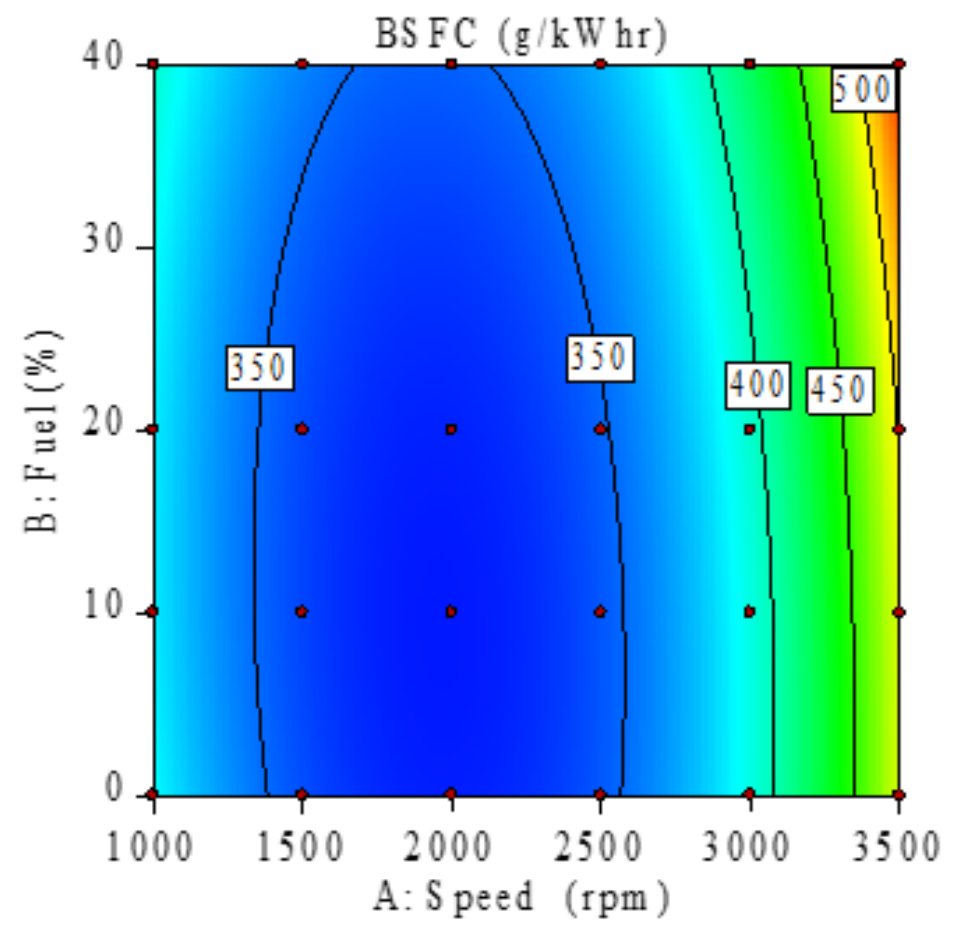

Fig. 4. Interactive effect of fuel blend and speed on BSFC

\subsection{Exhaust Emissions}

Carbon dioxide $\left(\mathrm{CO}_{2}\right)$ emissions are by-products of combustion. As seen from Figure 5, high $\mathrm{CO}_{2}$ emissions were observed in the operating speed range approximately from $1250 \mathrm{rpm}$ to nearly 2000 rpm after which it lowers down for baseline fuel diesel and PBD blends from $10 \%$ to $40 \%$. Highest $\mathrm{CO}_{2}$ emissions of 10.9 vol. \% was noted for baseline fuel diesel whereas for PBD40 was slightly 
reduced at 0.6 vol. \% for $1500 \mathrm{rpm}$. Biodiesels have higher $\mathrm{O}_{2}$ concentration and this leads to high $\mathrm{O}_{2}$ concentration in combustion region oxidizing $\mathrm{CO}$ to $\mathrm{CO}_{2}[29,30]$.

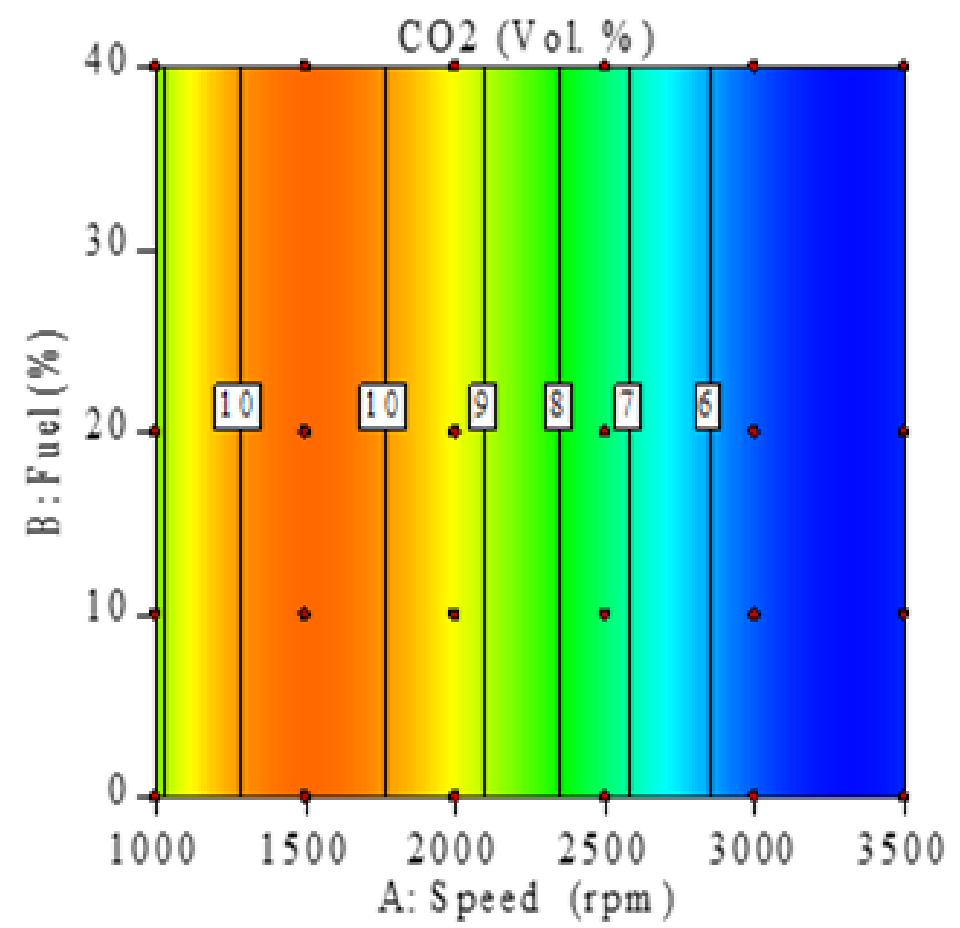

Fig. 5. Interactive effect of fuel blend and speed on $\mathrm{CO}_{2}$ emissions

Incomplete combustion causes Carbon Monoxide (CO) emissions formation in diesel engine. As seen from Figure 6, increased $\mathrm{CO}$ emissions were observed in the operating speed range from 1000 rpm to $1500 \mathrm{rpm}$ for baseline fuel diesel and PBD blends from $10 \%$ to near $40 \%$. Highest CO emissions of 0.028 vol. \% was noted for baseline fuel diesel whereas for PBD10 was slightly higher at 0.030 vol. $\%$ for $1500 \mathrm{rpm}$. Researchers point out that biofuels contain 10\% oxygen while diesel has zero presence of oxygen. Oxygen rich fuel combustion region increases the chances of complete combustion thereby reducing CO formation $[29,30]$.

Oxides of Nitrogen (NOx) emission formation is caused by reaction of nitrogen and oxygen at high flame temperature. As seen from Figure 7, elevated $\mathrm{NO}_{x}$ formation region is observed in the operating speed range from $1500 \mathrm{rpm}$ to nearly $3000 \mathrm{rpm}$ for baseline fuel diesel and PBD blends up to $40 \%$. Highest NOx emissions of 294 ppm was noted for baseline fuel diesel whereas for PBD20 was slightly higher at $304 \mathrm{ppm}$ for $2000 \mathrm{rpm}$. Researchers highlight that increased NOx emission is due to more oxygen content in PBD, presence of double bounds, higher viscosity and density in fuel, and also adding that a number of coupled reaction mechanisms may either strengthen or weaken NOx formation depending upon operating conditions [20,31-34]. 


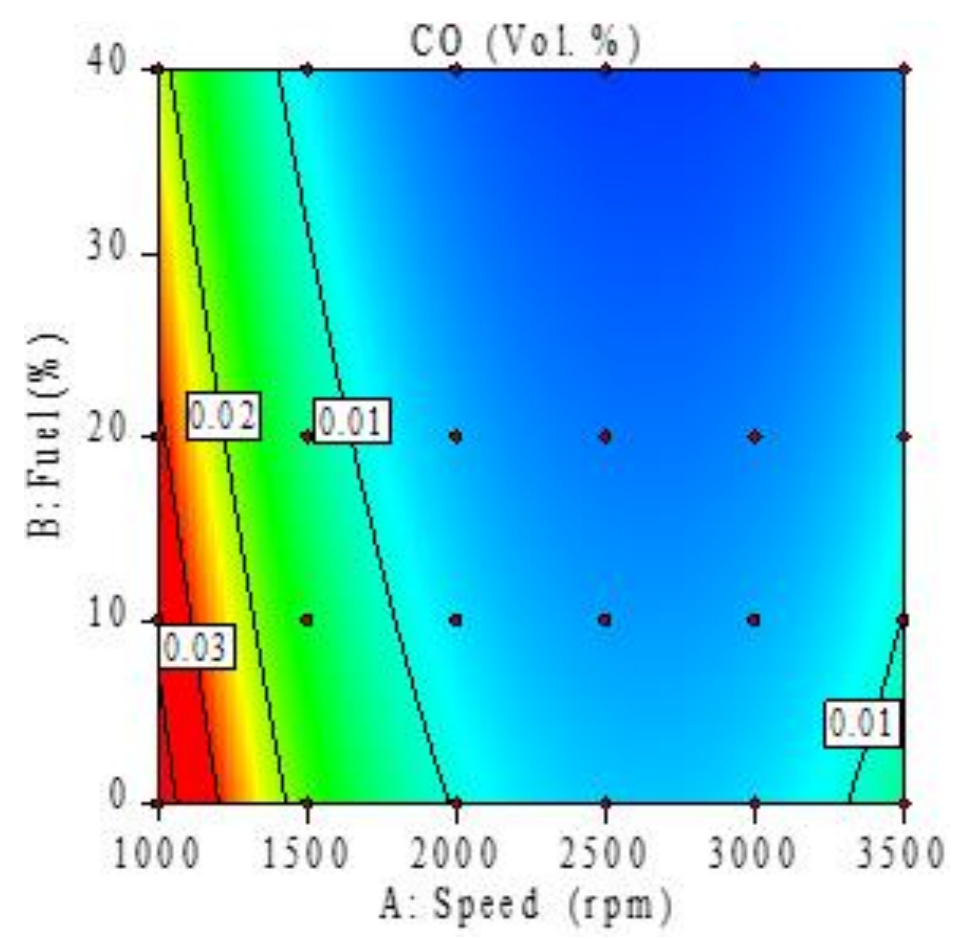

Fig. 6. Interactive effect of fuel blend and speed on CO emissions

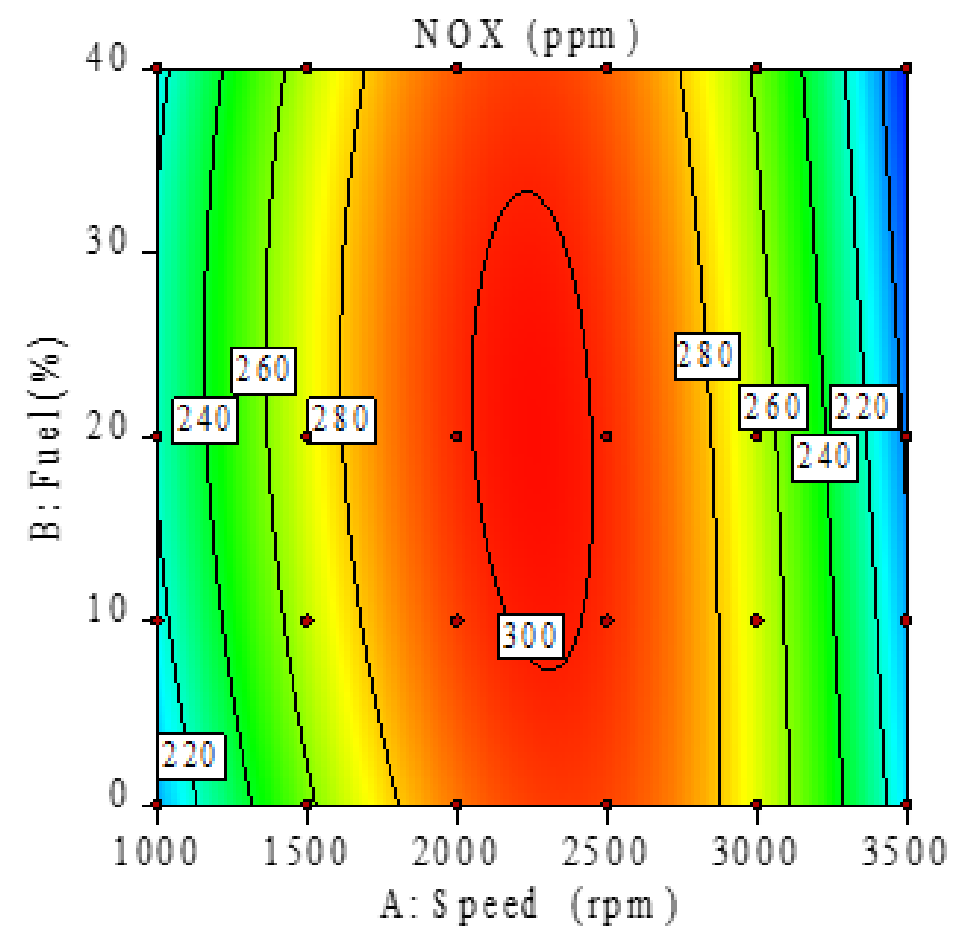

Fig. 7. Interactive effect of fuel blend and speed on $\mathrm{NO}_{\mathrm{x}}$ emissions

\section{Conclusions}

PBD blends of various ratios have been successfully tested in a multi cylinder diesel engine. The experimental data captured during the test were used for RSM analysis using a mathematical software. The concluding statements are as follows 
i. Highest power and torque of $29.6 \mathrm{hp}$ and $105.5 \mathrm{Nm}$ at $2000 \mathrm{rpm}$ is obtained for PBD10 compared to $28.7 \mathrm{hp}$ and $102.2 \mathrm{Nm}$ at $2000 \mathrm{rpm}$ for pure diesel fueling. Minimum BSFC attained at $2000 \mathrm{rpm}$ for PBD10 at $326.3 \mathrm{~g} / \mathrm{kWh}$ but slightly higher than diesel at $328.4 \mathrm{~g} / \mathrm{kWh}$.

ii. Highest $\mathrm{CO}_{2}, \mathrm{CO}$ and $\mathrm{O}_{2}$ emissions of 0.6 vol. \% (PBD40), 0.030 vol. \% (PBD10), 5.7 vol. \% (PBD10) was observed at $1500 \mathrm{rpm}$ compared to pure diesel at $10.9 \mathrm{vol}$. \%, $0.028 \mathrm{vol}$. \% and 5.50 vol. \%.

iii. NOx emissions increased to 304 ppm for PBD20 from 294 ppm for diesel at $2000 \mathrm{rpm}$. While lower smoke reduced from $54.9 \%$ for diesel to $49.7 \%$ for PBD10.

\section{Acknowledgement}

We gratefully thank the Ministry of Education (MOE) of Malaysia for support through USM Research University (RUI) Grant Scheme (1001.PMEKANIK.8014136) and UOW Malaysia KDU Penang University College internal research grant scheme. The authors would also like to acknowledge Universiti Sains Malaysia (School KPI grant) for financial support toward this study.

\section{References}

[1] Pattamaprom, Cattaleeya, Watit Pakdee, and Sureerat Ngamjaroen. "Storage degradation of palm-derived biodiesels: Its effects on chemical properties and engine performance." Renewable Energy 37, no. 1 (2012): 412418. https://doi.org/10.1016/j.renene.2011.05.032

[2] Mekhilef, Saad, S. Siga, and Rahman Saidur. "A review on palm oil biodiesel as a source of renewable fuel." Renewable and Sustainable Energy Reviews 15, no. 4 (2011): 1937-1949.

https://doi.org/10.1016/i.rser.2010.12.012

[3] Agarwal, Avinash Kumar. "Biofuels (alcohols and biodiesel) applications as fuels for internal combustion engines." Progress in Energy and Combustion Science 33, no. 3 (2007): 233-271. https://doi.org/10.1016/i.pecs.2006.08.003

[4] Abed, K. A., M. S. Gad, A. K. El Morsi, M. M. Sayed, and S. Abu Elyazeed. "Effect of biodiesel fuels on diesel engine emissions." Egyptian Journal of Petroleum 28, no. 2 (2019): 183-188. https://doi.org/10.1016/i.ejpe.2019.03.001

[5] Bari, S., and S. N. Hossain. "Performance and emission analysis of a diesel engine running on palm oil diesel (POD)." Energy Procedia 160 (2019): 92-99. https://doi.org/10.1016/i.egypro.2019.02.123

[6] Rosha, Pali, Saroj Kumar Mohapatra, Sunil Kumar Mahla, HaengMuk Cho, Bhupendra Singh Chauhan, and Amit Dhir. "Effect of compression ratio on combustion, performance, and emission characteristics of compression ignition engine fueled with palm (B20) biodiesel blend." Energy 178 (2019): 676-684. https://doi.org/10.1016/i.energy.2019.04.185

[7] Hirkude, Jagannath B., and Atul S. Padalkar. "Performance optimization of $\mathrm{Cl}$ engine fuelled with waste fried oil methyl ester-diesel blend using response surface methodology." Fuel 119 (2014): 266-273.

https://doi.org/10.1016/i.fuel.2013.11.039

[8] Fang, Wei, David B. Kittelson, and William F. Northrop. "Optimization of reactivity-controlled compression ignition combustion fueled with diesel and hydrous ethanol using response surface methodology." Fuel 160 (2015): 446457.

https://doi.org/10.1016/i.fuel.2015.07.055

[9] Saravanan, S., B. Rajesh Kumar, A. Varadharajan, D. Rana, and Balaji Sethuramasamyraja. "Optimization of DI diesel engine parameters fueled with iso-butanol/diesel blends-response surface methodology approach." Fuel 203 (2017): 658-670. https://doi.org/10.1016/j.fuel.2017.04.083

[10] Shamun, Sam, Can Haşimoğlu, Ahmet Murcak, Öivind Andersson, Martin Tunér, and Per Tunestål. "Experimental investigation of methanol compression ignition in a high compression ratio HD engine using a Box-Behnken design." Fuel 209 (2017): 624-633. https://doi.org/10.1016/i.fuel.2017.08.039

[11] Karmakar, Rachan, Krishnendu Kundu, and Anita Rajor. "Fuel properties and emission characteristics of biodiesel produced from unused algae grown in India." Petroleum Science 15, no. 2 (2018): 385-395. 
https://doi.org/10.1007/s12182-017-0209-7

[12] Ganjehkaviri, Abdolsaeid, Mohammad Nazri Mohd Jaafar, Seyed Ehsan Hosseini, and Anas Basri Musthafa. "Performance evaluation of palm oil-based biodiesel combustion in an oil burner." Energies 9, no. 2 (2016): 97. https://doi.org/10.3390/en9020097

[13] Sulaiman, Sarina, S. Rohana, P. Jamal, and Husna A. Tajuddin. "Effect of Amount of Catalyst, Agitation Rate, and Methanol to Oil Molar Ratio using Mixed Catalyst Derived from Coconut Waste and Eggshells." Journal of Advanced Research in Applied Sciences and Engineering Technology 1, no. 1 (2017): 1-5.

[14] Norhidayah, M., A. Shaaban, M. F. Dimin, M. Y. Norazlina, and O. Rostam. "Optimization of Biodegradable Urea Production Process to Minimize Ammonia Release through Response Surface Method Experimental Design." Journal of Advanced Research in Applied Sciences and Engineering Technology 2, no. 1 (2016): 9-18.

[15] Rahman, M. D. A., V. Jaganathan, M. A. Amil, and M. R. CheRose. "Optimization of Surface Roughness on S50 Carbon Steel in CNC Milling Machine using Response Surface Methodology." Journal of Advanced Research in Materials Science 45, no. 1 (2018): 15-26.

[16] Amil, M. A., M. Gaafar, M. D. A. Rahman, and M. R. CheRose. "Optimization of Surface Roughness on 6061-T6 Aluminium Alloy in CNC Milling Machine Using Response Surface Methodology." Journal of Advanced Research in Materials Science 46, no. 1 (2018): 1-9.

[17] Buyukkaya, Ekrem. "Effects of biodiesel on a DI diesel engine performance, emission and combustion characteristics." Fuel 89, no. 10 (2010): 3099-3105.

https://doi.org/10.1016/i.fuel.2010.05.034

[18] Mofijur, M., H. H. Masjuki, M. A. Kalam, and A. E. Atabani. "Evaluation of biodiesel blending, engine performance and emissions characteristics of Jatropha curcas methyl ester: Malaysian perspective." Energy 55 (2013): 879-887. https://doi.org/10.1016/i.energy.2013.02.059

[19] Sahoo, P. K., L. M. Das, M. K. G. Babu, P. Arora, V. P. Singh, N. R. Kumar, and T. S. Varyani. "Comparative evaluation of performance and emission characteristics of jatropha, karanja and polanga based biodiesel as fuel in a tractor engine." Fuel 88, no. 9 (2009): 1698-1707.

https://doi.org/10.1016/i.fuel.2009.02.015

[20] Ozsezen, Ahmet Necati, and Mustafa Canakci. "Determination of performance and combustion characteristics of a diesel engine fueled with canola and waste palm oil methyl esters." Energy Conversion and Management 52, no. 1 (2011): 108-116.

https://doi.org/10.1016/i.enconman.2010.06.049

[21] Tesfa, Belachew, Rakesh Mishra, C. Zhang, F. Gu, and A. D. Ball. "Combustion and performance characteristics of Cl (compression ignition) engine running with biodiesel." Energy 51 (2013): 101-115. https://doi.org/10.1016/i.energy.2013.01.010

[22] Kannan, G. R., Ramasamy Karvembu, and R. Anand. "Effect of metal based additive on performance emission and combustion characteristics of diesel engine fuelled with biodiesel." Applied Energy 88, no. 11 (2011): 3694-3703. https://doi.org/10.1016/i.apenergy.2011.04.043

[23] Candeia, R. A., M. C. D. Silva, J. R. Carvalho Filho, M. G. A. Brasilino, T. C. Bicudo, I. M. G. Santos, and A. G. Souza. "Influence of soybean biodiesel content on basic properties of biodiesel-diesel blends." Fuel 88, no. 4 (2009): 738743. https://doi.org/10.1016/i.fuel.2008.10.015

[24] MacLean, Heather L., and Lester B. Lave. "Evaluating automobile fuel/propulsion system technologies." Progress in Energy and Combustion Science 29, no. 1 (2003): 1-69.

https://doi.org/10.1016/S0360-1285(02)00032-1

[25] Haşimoğlu, Can, Murat Ciniviz, İbrahim Özsert, Yakup İçingür, Adnan Parlak, and M. Sahir Salman. "Performance characteristics of a low heat rejection diesel engine operating with biodiesel." Renewable Energy 33, no. 7 (2008): 1709-1715. https://doi.org/10.1016/j.renene.2007.08.002

[26] Ganapathy, T., R. P. Gakkhar, and K. Murugesan. "Influence of injection timing on performance, combustion and emission characteristics of Jatropha biodiesel engine." Applied Energy 88, no. 12 (2011): 4376-4386. https://doi.org/10.1016/i.apenergy.2011.05.016

[27] Qi, D. H., H. Chen, L. M. Geng, and Y. ZH Bian. "Experimental studies on the combustion characteristics and performance of a direct injection engine fueled with biodiesel/diesel blends." Energy Conversion and Management 51, no. 12 (2010): 2985-2992. https://doi.org/10.1016/i.enconman.2010.06.042

[28] Kinoshita, E., K. Hamasaki, and C. Jaqin. Diesel Combustion of Palm Oil Methyl Ester. No. 2003-01-1929. SAE Technical Paper, 2003.

https://doi.org/10.4271/2003-01-1929 
[29] Agarwal, Avinash Kumar, and L. M. Das. "Biodiesel development and characterization for use as a fuel in compression ignition engines." Journal of Engineering For Gas Turbines and Power 123, no. 2 (2001): 440-447. https://doi.org/10.1115/1.1364522

[30] Singh Yadav, Vinod, Kamal Kishore Khatri, Deepak Tanwar, Ajayta, Dilip Sharma, and S. L. Soni. "Performance analysis and exhaust emissions of neem methyl ester operated compression ignition engine." Journal of Renewable and Sustainable Energy 5, no. 2 (2013): 023101. https://doi.org/10.1063/1.4792475

[31] Mueller, Charles J., André L. Boehman, and Glen C. Martin. "An experimental investigation of the origin of increased NOx emissions when fueling a heavy-duty compression-ignition engine with soy biodiesel." SAE International Journal of Fuels and Lubricants 2, no. 1 (2009): 789-816.

https://doi.org/10.4271/2009-01-1792

[32] Sun, Jiafeng, Jerald A. Caton, and Timothy J. Jacobs. "Oxides of nitrogen emissions from biodiesel-fuelled diesel engines." Progress in Energy and Combustion Science 36, no. 6 (2010): 677-695. https://doi.org/10.1016/j.pecs.2010.02.004

[33] Tsolakis, Athanasios, A. Megaritis, M. L. Wyszynski, and Kampanart Theinnoi. "Engine performance and emissions of a diesel engine operating on diesel-RME (rapeseed methyl ester) blends with EGR (exhaust gas recirculation)." Energy 32, no. 11 (2007): 2072-2080. https://doi.org/10.1016/j.energy.2007.05.016

[34] Kalam, M. A., H. H. Masjuki, M. H. Jayed, and A. M. Liaquat. "Emission and performance characteristics of an indirect ignition diesel engine fuelled with waste cooking oil." Energy 36, no. 1 (2011): 397-402. https://doi.org/10.1016/i.energy.2010.10.026 